\title{
An Experimental Investigation of Different Washing Processes on Various Properties of Stretch Denim Fabric
}

\author{
Md. Zayedul Hasan, A. K. M. Ayatullah Hosne Asif* ${ }^{\circledR}$, Abdur Razzaque, Md. Rakibul Hasan, \\ Sudip Sur, Md. Omar Faruque
}

Department of Textile Engineering, Mawlana Bhashani Science and Technology University, Santosh, Tangail, Bangladesh

Email: *ayatasif.mbstu@gmail.com

How to cite this paper: Hasan, Md.Z., Asif, A.K.M.A.H., Razzaque, A., Hasan, Md.R., Sur, S. and Faruque, Md.O. (2021) An Experimental Investigation of Different Washing Processes on Various Properties of Stretch Denim Fabric. Journal of Materials Science and Chemical Engineering, 9, $1-15$.

https://doi.org/10.4236/msce.2021.91001

Received: November 17, 2020

Accepted: January 16, 2021

Published: January 19, 2021

\section{Copyright $\odot 2021$ by author(s) and} Scientific Research Publishing Inc. This work is licensed under the Creative Commons Attribution International License (CC BY 4.0).

http://creativecommons.org/licenses/by/4.0/ (c) (i) Open Access

\begin{abstract}
This research work was designed to explore the effect of different washing processes (enzyme wash, enzyme stone wash, enzyme stone wash with bleaching, heavy enzyme stone wash with bleaching) on various properties of stretch denim fabric. Different properties like tensile strength, tear strength, dimensional stability to washing, color fastness to washing, color fastness to water, color fastness to perspiration, color fastness to light, color fastness to rubbing, changes in fabric weight were investigated in context with different washing processes for stretch denim fabric. All tests were carried out according to the ISO (International Organization for Standardization). Enzyme washed fabric illustrated better performance regarding tear strength, tensile strength and dimensional stability; but showed moderate performance in different color fastness properties. But the color fastness to rubbing of heavy enzyme stone wash was excellent. No significant change was observed regarding the grade of color change and color staining for color fastness to wash, color fastness to perspiration and color fastness to light with respect to different types of washing processes like enzyme wash, enzyme stone wash, enzyme stone wash with bleaching and heavy enzyme stone wash with bleaching. The grade for dry rubbing and wet rubbing was comparatively better for enzyme wash rather than other washing processes. The GSM (gram per square meter) of stretch denim fabric also increased accordingly after different kinds of washing process rather than untreated stretch denim fabric. The dimensional stability of stretch denim fabric also altered after going through different washing process. The highest shrinkage was occurred in weft direction for heavy enzyme stone wash with bleaching.
\end{abstract}

\section{Keywords}

Enzyme Wash, Stone Enzyme Wash, Stretch Denim, Bleaching, Tensile Strength 


\section{Introduction}

Technically denim is durable and strong cotton warp-faced textile material in which the weft thread passes under two or extra warp threads [1] [2]. This twill weave structure produces a diagonal design which differentiates it from cotton duck fabric [3] [4]. Denim is considered as the oldest fashion products in the world [5] [6] [7]. Denim fabric is made of cotton twill weave structure with $100 \%$ cotton and very comfortable to feel [8] [9]. This fabric is used to manufacture jeans, jackets, shirts, purses, bags, and many other fashion items for men and women of all ages around the world [10] [11] [12]. Denim fabric constitutes sturdy outlook, durable textile prepared from cotton fibers using twill weave structure [13] [14]. In modern fashion world, it also secures substitute usage as performance and application-based textile materials for the manufacturing of seat covers, mobile cases, insulation textiles [15] [16]. There is no denying of the fact that, scientific and leading-edge technological advancement regarding the product development, process optimization in textile manufacturing significantly changes the concepts of traditional manufacturing in lieu of sustainable manufacturing [17] [18] [19]. Moreover, over the last few decades, denim garments unquestionably hold position in the fashion industry and her ability to adapt creativeness in fashion inclinations through her extraordinariness along with numerous advanced washing effects [20] [21]. Stretch denim is a type of jeans product mostly associated with cotton-polyester blend that assimilates a small amount of elastane known as spandex [22] [23]. Structurally stretch denim constructed with indigo dyed warp thread and white weft thread alongside encompasses about $1 \%-3 \%$ elastane [24] [25]. The weft threads of the denim fabric extend along the entire width of the fabric [26]. For denim washing, enzymes are primarily used to obtain a cleaner surface [27]. For aesthetic finish and improving the attractiveness of the denim fabric, enzymes have played a significant role not only providing an artistic outlook but also reducing pills, increasing smoothness, luster, brightness, improvement of fabric maneuverability and coating ability, and enlightening vintage effects that encounter trend requirements in modern fashion world [28] [29].

Among different processing involved in denim garments manufacturing, washing process is considered as one of the important process parameters [30]. Washing process imparts value addition attributes to the final product [31]. Several washing methods involved in denim processing persuade different effects like fading and vintage [32]. Traditional washing process constitutes acid wash, enzyme washing, spray techniques, stone enzyme washing with strong bleaching agents such as sodium hypochlorite, potassium permanganate although these processes are not sustainable and environmentally friendly [33] [34]. Furthermore, cellulase enzymes instead of pumice stones help to achieve not only an abrasive effect but also special outlook on denim garments [35]. Technological advancement regarding the sustainable washing, green dyeing also took place for textile materials processing during the recent years [36] [37]. Various types of 
newly introduced denim of exotic designs supplemented with lightness, smoothness and comfortability sensational features have added a new height to the fashion arena [38]. Recently conducted various research works emphasized about the development of various washing treatments for denim processing [39] [40]. So, current research work about the understanding of different washing treatment on various properties like tensile strength, tear strength, dimensional stability to washing, color fastness to washing, color fastness to water, color fastness to perspiration, color fastness to light, color fastness to rubbing, changes in fabric weight for stretch denim fabric will contribute to enrich the scopes of study on denim washing. Therefore, the primary aim of this study was to determine the different properties of stretch denim fabric treated with various washing process.

\section{Materials and Methods}

\subsection{Material}

\section{Fabric}

In this research work, $99 \%$ of cotton $1 \%$ of elastane indigo dyed stretch denim fabrics was used. The fabric GSM (grams per square meter) was 340 (Before wash), 3/1 right hand twill fabric; width 57 inch.

\section{Chemicals}

For the experimentation, de-sizing agent soda ash (sodium carbonate), detergent (Hotspur, BASF), bleaching powder (Bleach KCI, 35\% available chlorine), enzyme (Genzyme SL (cellulase enzyme)), silicone (Text-soft, BASF) softener were also used for this study.

\section{Experimental Instruments}

For this experiment, washing machine, hydro extractor machine, tumble dryer machine, fabric GSM cutter, perspirometer perspiration tester for testing the color fastness to perspiration, crockmeter/rubbing fastness tester, electronic balance and fabric $\mathrm{pH}$ meter were used.

\subsection{Methodology}

\subsubsection{Working Procedure of Enzyme Wash}

In the garments washing, de-sizing is the first step of enzyme wash. This step was used for removing dirt, dust and other foreign materials from garments surface. Here wetting agent was used to increase the penetrating property of liquid into the garments. Material and liquor ratio were kept at 1:8; then run the machine with addition of de-sizing agent $1.1 \mathrm{~g} / \mathrm{l}$, soda ash $2 \mathrm{~g} / \mathrm{l}$ and wetting agent $1.5 \mathrm{~g} / \mathrm{l}$. The temperature was set $50^{\circ} \mathrm{C}$ for 15 minutes. Then the liquor was dropped out by following cold wash. In the bio-abrasion process, hairy fibers were removed and coloring materials were also removed by the activity of enzyme. Then addition of anti-back staining agent about $2.0 \mathrm{~g} / \mathrm{l}$ with acid enzyme $0.6 \%$ was done accordingly. The $\mathrm{pH}$ for acid enzyme was maintained for 4.5 to 5.5 and the temperature was kept $55^{\circ} \mathrm{C}$ to run the process for 50 minutes. Then 
dropped the liquor and cold wash was done. For conducting back wash, material and liquor ratio were kept for $1: 8$; then run the machine by adding $3.0 \mathrm{~g} / \mathrm{l}$ anti back staining with soda ash $0.3 \mathrm{~g} / \mathrm{l}$. The temperature was maintained at $70^{\circ} \mathrm{C}$ to run for 10 minutes. Then dropped the liquor and rinse wash was done. Subsequently softening operation was conducted and the temperature was kept cold to run for 5 minutes. Then liquor was dropped by following rinse wash. After completing the aforementioned washing process the liquor was dropped out, unload the garments and hydro extracted at $200 \mathrm{rpm}$ for $3-4 \mathrm{~min}$ to remove the excess water. At last garments were dried at $75^{\circ} \mathrm{C}$ for $35-40$ min by steam dryer.

\subsubsection{Working Procedure of Stone Enzyme Wash}

Enzyme stone washing process generally used to produce worn-out outlook on denim fabric. This stone washing process was conducted by washing stretch denim fabric with pumice stones in a rotating drum by using chemicals to create desired appearance. Here stone enzyme washing process was conducted by different steps like de-sizing, bio-abrasion, addition and tumble of pumice stones with enzyme along with acetic acid and anti-stain agent at $40^{\circ} \mathrm{C}-50^{\circ} \mathrm{C}$ for 40 60 minutes depending on the desired outlook, drain the liquor and separate the garments from pumice stones, softening with softener accordingly and hydro extracting procedures.

\subsubsection{Working Procedure of Stone Enzyme Wash with Bleaching}

De-sizing is the first step of enzyme wash. This step was used for removing dirt, dust and other foreign materials from garments surface. Material and liquor ratio were about 1:8; then run the machine with addition of de-sizing agent $1.1 \mathrm{~g} / \mathrm{l}$, soda ash $2 \mathrm{~g} / \mathrm{l}$ and wetting agent $1.5 \mathrm{~g} / \mathrm{l}$. Wetting agent was used to increase the penetrating property of liquid into the fabric sample. The temperature was kept $50^{\circ} \mathrm{C}$ for 15 minutes. Then the liquor was dropped out by following cold wash. For bio-abrasion, addition of anti-back staining agent about $2 \mathrm{~g} / \mathrm{l}$ with acid enzyme $0.6 \%$ was performed. The $\mathrm{pH}$ for acid enzyme was 4.5 to 5.5 and the temperature was maintained $55^{\circ} \mathrm{C}$ to run for 50 minutes. Then dropped the liquor and cold wash was done. Then the samples were treated with cellulase enzyme in the washing machine at $1.1 \mathrm{~g} / \mathrm{l}$ concentration of bleaching powder (KCI) and Genzyme SL $(2 \mathrm{~g} / \mathrm{l})$, temperature $40^{\circ} \mathrm{C}$ and the time was kept 20 mins with pumice stones. This process was conducted containing acetic acid $(1 \mathrm{~g} / \mathrm{l})$ at pH 5.5 and material to liquor ratio 1:8. All of the treatments were performed in the rotary cylindrical washing machine at speed of $30 \mathrm{rpm}$. Then samples were washed with hot water and cold water at room temperature for 5 minutes. Finally, samples were softened with Text-soft softener $(2.5 \mathrm{~g} / \mathrm{l})$ at room temperature for 5 minutes. For back wash process, material and liquor ratio also kept for 1:30; then run the machine by adding $3 \mathrm{~g} / \mathrm{l}$ anti back staining agent with soda ash $0.3 \mathrm{~g} / \mathrm{l}$. The temperature was controlled for $70^{\circ} \mathrm{C}$ to run for 10 minutes. Then the liquor was dropped out followed by rinse wash. After completing the above-mentioned washing process the liquor was dropped, unload the garments and hydro ex- 
tracted at $200 \mathrm{rpm}$ for $3-4$ min to remove the excess water. At last garments were dried at $75^{\circ} \mathrm{C}$ for $35-40 \mathrm{~min}$ by gas dryer or steam dryer.

\subsubsection{Working Procedure of Heavy Stone Enzyme Wash with Bleaching}

Heavy enzyme stone washing with bleaching process was conducted by washing stretch denim fabric with pumice stones in a rotating drum by using chemicals to create desired appearance. In this experiment, different steps like de-sizing, bio-abrasion, addition and tumble of pumice stones with enzyme along with acetic acid and anti-stain at $40^{\circ} \mathrm{C}-50^{\circ} \mathrm{C}$ for $40-60$ minutes depending on the desired outlook, drain the liquor and separate the garments from pumice stones, so. Then the samples were treated with cellulase enzyme in the washing machine at $1.3 \mathrm{~g} / \mathrm{l}$ concentration of bleaching powder, KCI and Genzyme SL (2 g/l), temperatures $40^{\circ} \mathrm{C}$ and the time was kept 20 mins with pumice stones. This process was conducted in liquor containing acetic acid $(1 \mathrm{~g} / \mathrm{l})$ at $\mathrm{pH} 5.5$ and material to liquor ratio 1:8. All treatment were performed in the rotary cylindrical washing machine at $30 \mathrm{rpm}$. Then the samples were washed with hot water along with cold water at room temperature for 5 minutes. Then softening process was done with softener accordingly followed by hydro extracting procedures.

\subsubsection{Measurement of Color Fastness Properties}

The following color fastness tests were done for this research work [41] [42] [43] [44] [45]:

- Color fastness to wash (Method: ISO $105 \mathrm{C10})$

- Color fastness to rubbing (Method: ISO 105 X12)

- Color fastness to light (Method: ISO 105 B02)

- Color fastness to water (Method: ISO 105 E01)

- Color fastness to perspiration (Method: ISO 105 E04)

\subsubsection{Determination of Dimensional Stability}

Dimensional stability of the sample was measured according to ISO 23231 [46] which postulates about an accelerated procedure for the understanding of dimensional changes of fabrics those will be used to produce garments and will be laundered in a variety of situations. This standard signifies a procedure which implies an apparatus with programmable settings simulate numerous domestic and industrial laundering actions and wet processing operations in fabric manufacturing. In this research, this standard method was used for the determination of dimensional change. After washing, drying, conditioning and measuring the specimen, the change in dimension was calculated.

Dimensional Change $(\%)=\{($ Dimension after wash - Original dimension $) \times$ $100\} /$ Original dimension.

Sample Conditioning: Conditioning specimen at least 4 hours as per ISO 139 prior to preparing and measuring.

Testing Condition: Temperature $-(20 \pm 2)^{\circ} \mathrm{C}$ and Relative humidity $(65 \pm$ 4)\%.

Specimen size: As per template. 


\subsubsection{Determination of Tensile Strength}

This tensile strength test was conducted according to ISO 13934 [47]. This method specifies about the determination of the maximum force of textile fabrics known as the grab test. For experimentation, test specimen gripped in its center part by jaws of specified dimensions, extended at constant rate until it ruptures. Then the maximum force was recorded.

Testing Method: ISO 13934-2 (grab test).

Testing Condition: Temperature $=(20 \pm 2)^{\circ} \mathrm{C}$, Relative humidity $=(65 \pm 2) \%$.

Sample size: $200 \mathrm{~mm} \times 100 \mathrm{~mm}$.

Apparatus: Titan-Universal Strength Tester, air compressor, computer.

\subsubsection{Determination of Tear Strength}

The determination of tear strength of different fabric samples treated with various washing processes were measured according to ISO 13937-1 [48]. Tear strength is the resistance of the fabric against tearing or force required to propagate the tear once it is initiated. The tear strength is required in high performance applications and in conventional textiles like bulletproof jackets, tents, aesthetic apparel. This is also important in the industrial textiles where heavy duty work is performed. The average reading was recorded as tear strength in $\mathrm{N}$.

Sample Conditioning: Conditioning specimen at least 4 hours as per ISO 139.

Testing Condition: Temperature $-(20 \pm 2)^{\circ} \mathrm{C}$ and Relative humidity $(65 \pm$ 4)\%.

Specimen size: As per template.

Apparatus: Tearing tester, different capacity load, conditioning rack, calibrated ruler.

\section{Results and Discussion}

\subsection{Determination of Color Fastness to Wash for Different Types of Washing Processes of Stretch Denim Fabric}

Table 1 represents about the result of color fastness to wash of stretch denim fabric for enzyme wash, enzyme stone wash, enzyme stone wash with bleaching and heavy enzyme stone wash with bleaching. The grade for color change and

Table 1. Effect of various washing processes on color fastness to wash of stretch denim fabric.

\begin{tabular}{|c|c|c|c|c|c|c|c|c|}
\hline \multirow{2}{*}{$\begin{array}{l}\text { Sl. } \\
\text { No. }\end{array}$} & \multirow{2}{*}{$\begin{array}{l}\text { Different Types of } \\
\text { Washing Processes }\end{array}$} & \multirow{2}{*}{$\begin{array}{c}\text { Grade } \\
\text { (Change } \\
\text { in Color) }\end{array}$} & \multicolumn{6}{|c|}{ Grade (Color Staining on Multi Fiber) } \\
\hline & & & Acetate & Cotton & Nylon & Polyester & Acrylic & Wool \\
\hline 1 & Enzyme wash & 3 & 3 & $3-4$ & 3 & 4 & 3 & 3 \\
\hline 2 & Enzyme stone wash & $3-4$ & $3-4$ & 4 & $3-4$ & 4 & 4 & $3-4$ \\
\hline 3 & $\begin{array}{c}\text { Enzyme stone wash } \\
\text { with bleaching }\end{array}$ & 4 & 4 & 4 & 4 & $3-4$ & 4 & 4 \\
\hline 4 & $\begin{array}{l}\text { Heavy enzyme stone } \\
\text { wash with bleaching }\end{array}$ & 4 & 4 & 4 & 4 & 4 & 4 & 4 \\
\hline
\end{tabular}


color staining was moderate for enzyme wash rather than others. In case of enzyme wash, fabric lost its appearance when it came in contact with water during washing. On the other hand, enzyme stone wash with bleaching and heavy enzyme stone wash with bleaching illustrated relatively good performance rather than enzyme and enzyme stone wash.

\subsection{Determination of Color Fastness to Water for Different Types of Washing Processes of Stretch Denim Fabric}

Table 2 represents about the result of color fastness to water of stretch denim fabric for enzyme wash, enzyme stone wash, enzyme stone wash with bleaching and heavy enzyme stone wash with bleaching. The grade for color change and color staining was almost same for every aspect and no significant change was observed.

\subsection{Determination of Color Fastness to Perspiration (Acidic and Alkaline) for Different Types of Washing Processes of Stretch Denim Fabric}

Table 3 and Table 4 illustrate about the result of color fastness to perspiration (acidic and alkaline) of stretch denim fabric for enzyme wash, enzyme stone wash, enzyme stone wash with bleaching and heavy enzyme stone wash with bleaching. The grade for color change and color staining was almost same for every aspect and no significant change was observed.

Table 2. Effect of various washing processes on color fastness to water of stretch denim fabric.

\begin{tabular}{|c|c|c|c|c|c|c|c|c|}
\hline \multirow{2}{*}{$\begin{array}{l}\text { Sl. } \\
\text { No. }\end{array}$} & \multirow{2}{*}{$\begin{array}{l}\text { Different Types of } \\
\text { Washing Processes }\end{array}$} & \multirow{2}{*}{$\begin{array}{c}\text { Grade } \\
\text { (Change } \\
\text { in Color) }\end{array}$} & \multicolumn{6}{|c|}{ Grade (Color Staining on Multi Fiber) } \\
\hline & & & Acetate & Cotton & Nylon & Polyester & Acrylic & Wool \\
\hline 1 & Enzyme wash & $3-4$ & 4 & $3-4$ & 3 & 4 & 3 & $3-4$ \\
\hline 2 & Enzyme stone wash & 4 & 4 & 4 & $3-4$ & $3-4$ & 4 & 4 \\
\hline 3 & $\begin{array}{c}\text { Enzyme stone wash } \\
\text { with bleaching }\end{array}$ & 4 & 4 & 4 & 4 & 4 & 4 & 4 \\
\hline 4 & $\begin{array}{l}\text { Heavy enzyme stone } \\
\text { wash with bleaching }\end{array}$ & 4 & 4 & 4 & 4 & 4 & 4 & 4 \\
\hline
\end{tabular}

Table 3. Effect of various washing processes on color fastness to perspiration (acidic) of stretch denim fabric.

\begin{tabular}{|c|c|c|c|c|c|c|c|c|}
\hline \multirow{2}{*}{$\begin{array}{l}\text { Sl. } \\
\text { No. }\end{array}$} & \multirow{2}{*}{$\begin{array}{l}\text { Different Types of } \\
\text { Washing Processes }\end{array}$} & \multirow{2}{*}{$\begin{array}{c}\text { Grade } \\
\text { (Change } \\
\text { in Color) }\end{array}$} & \multicolumn{6}{|c|}{ Grade (Color Staining on Multi Fiber) } \\
\hline & & & Acetate & Cotton & Nylon & Polyester & Acrylic & Wool \\
\hline 1 & Enzyme wash & $3-4$ & 4 & $3-4$ & 3 & 4 & 3 & $3-4$ \\
\hline 2 & Enzyme stone wash & 4 & 4 & 4 & 4 & 4 & 4 & $4-5$ \\
\hline 3 & $\begin{array}{l}\text { Enzyme stone wash } \\
\text { with bleaching }\end{array}$ & 4 & $4-5$ & 4 & 4 & 4 & 4 & 4 \\
\hline 4 & $\begin{array}{l}\text { Heavy enzyme stone } \\
\text { wash with bleaching }\end{array}$ & 4 & 4 & 4 & $4-5$ & 4 & $4-5$ & 4 \\
\hline
\end{tabular}


Table 4. Effect of various washing processes on color fastness to perspiration (alkaline) of stretch denim fabric.

\begin{tabular}{cccccccccc}
\hline & & Grade & & \multicolumn{5}{c}{ Grade (Color Staining on Multi Fiber) } \\
\cline { 5 - 9 } No. & Different Types of & $\begin{array}{c}\text { Washing Processes } \\
\text { (Change } \\
\text { in Color) }\end{array}$ & Acetate & Cotton & Nylon & Polyester & Acrylic & Wool \\
\hline $\mathbf{1}$ & Enzyme wash & $3-4$ & 4 & $3-4$ & 3 & 4 & 3 & $3-4$ \\
$\mathbf{2}$ & Enzyme stone wash & 4 & 4 & 4 & $4-5$ & 4 & 4 & $4-5$ \\
$\mathbf{3}$ & $\begin{array}{c}\text { Enzyme stone wash } \\
\text { with bleaching }\end{array}$ & 4 & 4 & 4 & 4 & $4-5$ & 4 & $4-5$ \\
$\mathbf{4}$ & $\begin{array}{c}\text { Heavy enzyme stone } \\
\text { wash with bleaching }\end{array}$ & 4 & 4 & 4 & 4 & 4 & $4-5$ & 4 \\
\hline
\end{tabular}

\subsection{Determination of Color Fastness to Light for Different Types of Washing Processes of Stretch Denim Fabric}

Table 5 illustrates about the result of color fastness to light of stretch denim fabric for enzyme wash, enzyme stone wash, enzyme stone wash with bleaching and heavy enzyme stone wash with bleaching. The performance was almost same for every aspect and no significant change was observed.

\subsection{Determination of Color Fastness to Rubbing for Different Types of Washing Processes of Stretch Denim Fabric}

Table 6 represents about the result of color fastness to rubbing of stretch denim fabric for enzyme wash, enzyme stone wash, enzyme stone wash with bleaching and heavy enzyme stone wash with bleaching. The grade for dry and wet rubbing was relatively better for enzyme wash rather than others.

\subsection{Determination of Tensile Strength for Different Types of Washing Processes of Stretch Denim Fabric}

Figure 1 represents about the effect of washing process for tensile strength of stretch denim fabric. Highest strength was obtained in warp direction for enzyme washed stretch denim fabric due to the formation of weaving subjected to considerable tensions, particularly in the warp direction. In subsequent finishing processes such as calendaring, this stretch was increased and temporarily set in the fabric. Enzyme wash was more suitable and durable because the tensile strength showed great result rather than others.

\subsection{Determination of Tear Strength for Different Types of Washing Processes of Stretch Denim Fabric}

Figure 2 represents about the effect of washing process for tensile strength of stretch denim fabric in the warp and weft way direction. The diagram shows that the tear strength noticeably decreased in heavy enzyme stone wash with bleaching washed fabric in both direction of fabric. This was occurred due to bleaching powder first attacked on dyed yarn portion, decomposed them slowly and fibers are partly degraded along with polymer chain and step by step penetrated inside 


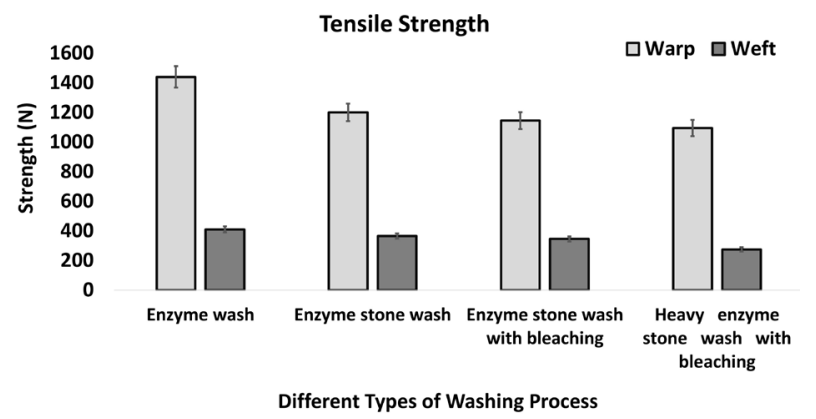

Figure 1. Variation of washing process for tensile strength of stretch denim fabric.

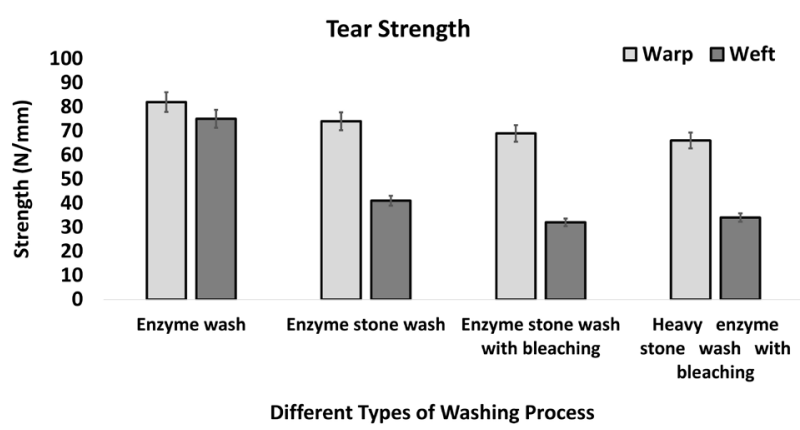

Figure 2. Variation of washing process for tear strength of stretch denim fabric.

Table 5. Effect of various washing processes on color fastness to light of stretch denim fabric.

\begin{tabular}{ccc} 
Sl. No. & Different Types of Washing Processes & $\begin{array}{c}\text { Fastness Rating according to } \\
\text { Blue Wool Standard Grading }\end{array}$ \\
\hline $\mathbf{1}$ & Enzyme wash & 5 \\
$\mathbf{2}$ & Enzyme stone wash & $5-6$ \\
$\mathbf{3}$ & Enzyme stone wash with bleaching & $5-6$ \\
$\mathbf{4}$ & Heavy enzyme stone wash with bleaching & $5-6$ \\
\hline
\end{tabular}

Table 6. Effect of various washing process on color fastness to rubbing of stretch denim fabric.

\begin{tabular}{cccc}
\hline S1. No. & $\begin{array}{c}\text { Different Types of } \\
\text { Washing Processes }\end{array}$ & $\begin{array}{c}\text { Grade } \\
\text { (Dry Rubbing) }\end{array}$ & $\begin{array}{c}\text { Grade } \\
\text { (Wet Rubbing) }\end{array}$ \\
\hline $\mathbf{1}$ & Enzyme wash & $4-5$ & $4-5$ \\
$\mathbf{2}$ & Enzyme stone wash & 3 & $3-4$ \\
$\mathbf{3}$ & Enzyme stone wash with bleaching & $3-4$ & 3 \\
$\mathbf{4}$ & Heavy enzyme stone wash with bleaching & 3 & 3 \\
\hline
\end{tabular}

the fabric. Therefore, the chemical bond of primary wall (outer layer) is broken by the decomposition of the aqueous solution of hypochlorite bleach which attacked on secondary wall. For this consequence, the primary wall (outer layer) of the cotton fiber was loosened and broken down quicker with the friction (me- 
chanical forces) of rotating cylinder of the washing machine. The second maximum tear strength loss was observed in heavy stone enzyme wash with bleaching due to the improper neutralization of enzyme and that enzyme remained active in indigo dyed denim fabric surface which reduced the tear strength. Experimentally, enzyme wash was the most durable washing process for stretch denim fabric in terms of tearing strength because less amount of strength loss was observed here compared to the other washing process.

\subsection{Determination of Fabric GSM for Different Types of Washing of Stretch Denim Fabric}

Figure 3 shows about the effect of various washing process on fabric GSM. From the diagram it can be observed that the maximum fabric weight was obtained from the enzyme wash process because of there is no use of bleaching powder in this washing process. In stone washing the friction between stone and fabric took place because of the use of pumice stone. Higher the GSM constitute higher compactness in yarn of stretch denim fabric and increase the strength of the fabric due to compactness.

\subsection{Determination of Dimensional Stability for Different Types of Washing Processes of Stretch Denim Fabric}

Table 7 illustrates about the result for dimensional stability in terms of shrinkage $\%$ of stretch denim fabric for different types of washing process like enzyme wash, enzyme stone wash, enzyme stone wash with bleaching and heavy enzyme stone wash with bleaching. It can be observed that the dimensional stability of

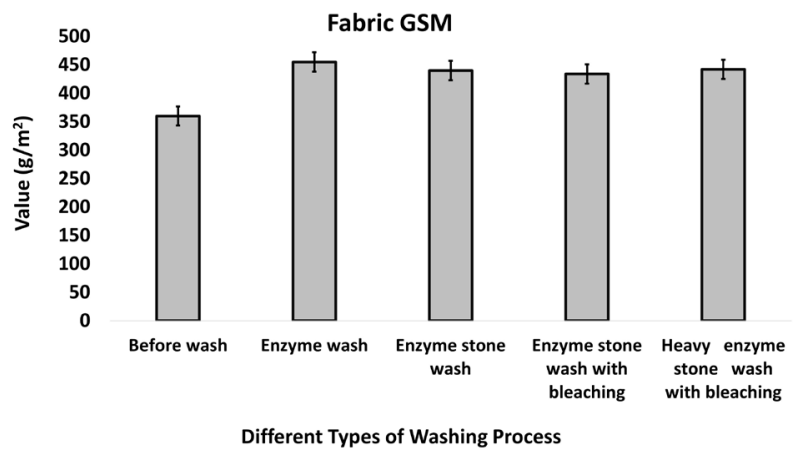

Figure 3. Variation of washing process for GSM of stretch denim fabric.

Table 7. Effect of various washing processes on dimensional stability of stretch denim fabric.

\begin{tabular}{cccc}
\hline & & \multicolumn{2}{c}{ Shrinkage } \\
\cline { 3 - 3 } Sl. No. & Different types of washing processes & Warp & Weft \\
\cline { 3 - 3 } $\mathbf{1}$ & Enzyme wash & $0.0 \%$ & $-1.0 \%$ \\
$\mathbf{n}$ & Enzyme stone wash & $+1.0 \%$ & $-1.0 \%$ \\
$\mathbf{4}$ & Heavy enzyme stone wash with bleaching & $+0.5 \%$ & $-1.5 \%$ \\
\hline
\end{tabular}


enzyme wash was good in warp and weft direction compared to the other washing process. Stretch denim fabric was subjected to considerable tensions, particularly in the warp direction. In subsequent finishing process such as calendaring; this stretch was increased and temporarily set in the fabric. The fabric was then in a state of dimensional instability. Subsequently when the denim garment was thoroughly wetted in bleach washing, it tended to retire its more stable dimensions which results in the contraction of the yarns. This effect was remarkable in the warp direction than in the weft direction. In different enzyme stone washing process, friction was occurred between denim fabric along with pumice stones and noticeable shrinkage\% were occurred.

\section{Conclusion}

In this research work, different types of washing processes like enzyme wash, enzyme stone wash, enzyme stone wash with bleaching and heavy enzyme stone wash with bleaching were applied on stretch denim fabric to investigate the changes in fabric weight, dimensional stability, tensile strength, tearing strength and different color fastness properties. Stretch denim was selected particularly to conduct this experiment because in modern fashion arena, this type of denim fabric is considered as the one of the most popular type denim fabrics. The grade for color change and color staining was moderate for enzyme wash. No significant change was observed for the grade of color change and color staining of color fastness to wash, color fastness to perspiration and color fastness to light with respect to different types of washing processes like enzyme wash, enzyme stone wash, enzyme stone wash with bleaching and heavy enzyme stone wash with bleaching. The grade for dry and wet rubbing was relatively better for enzyme wash rather than other washing processes. Stretch denim fabric treated with enzyme wash illustrated more suitable and durable performance because the tensile strength and tearing strength showed great result in warp and weft direction rather than enzyme stone wash, enzyme stone wash with bleaching and heavy enzyme stone wash with bleaching. The dimensional stability of stretch denim fabric also is changed by applying different washing processes. The highest shrinkage was occurred in weft direction for heavy enzyme stone wash with bleaching. Better performance was observed in warp direction for enzyme wash. The GSM of stretch denim fabric also increased accordingly after different kinds of washing processes rather than untreated stretch denim fabric. In a nutshell, engineers and concerned authority will be more thoughtful about the application of relevant washing process for stretch denim fabrics processing based on this research. This scientific exploration will surely benefit consumers and manufacturers to attain the best possible outcome from the finished goods based on the knowledge of different washing processes in reference to fabric weight, dimensional stability, tensile strength, tear strength and color fastness properties.

\section{Acknowledgements}

The authors gratefully acknowledge the Department of Textile Engineering of 
Mawlana Bhashani Science and Technology University (MBSTU) and Windy Group for technical support of this work.

\section{Compliance with Ethics Requirements}

This article does not contain any studies with human or animal subjects performed by any of the authors.

\section{Conflicts of Interest}

All the authors do not have any possible conflicts of interest.

\section{References}

[1] Shahid, M., Zhou, Y., Tang, R.C. and Chen, G. (2016) Enzymatic Washing of Denim: Greener Route for Modern Fashion. In: Muthu, S.S., Ed., Textiles and Clothing Sustainability, Springer, Berlin, 67-83. https://doi.org/10.1007/978-981-10-2474-0 3

[2] Patra, A.K., Madhu, A. and Bala, N. (2018) Enzyme Washing of Indigo and Sulphur Dyed Denim. Fashion and Textiles, 5, Article No. 3. https://doi.org/10.1186/s40691-017-0126-9

[3] Kan, C.W. (2014) Effect of Enzyme Washing on the Tensile Property of Denim Fabric. Advanced Materials Research, 933, 175-178. https://doi.org/10.4028/www.scientific.net/AMR.933.175

[4] Ek, C., HA, E., GK, G., O, S., and C, S. (2018) Effect of Washing Cycle on Tenacity and Stretching Properties of Denim Fabrics Containing Elastane. Journal of Fashion Technology and Textile Engineering, s5, 003. https://doi.org/10.4172/2329-9568.S5-003

[5] Elmogahzy, Y.E. (2020) Performance Characteristics of Traditional Textiles: Denim and Sportswear Products. In: Elmogahzy, Y.E., Ed., Engineering Textiles, Elsevier, Amsterdam, 319-346. https://doi.org/10.1016/B978-0-08-102488-1.00013-7

[6] Patra, A.K. and Pattanayak, A.K. (2015) Novel Varieties of Denim Fabrics. In: Paul, R., Ed., Denim, Woodhead Publishing Limited, Cambridge, 483-506. https://doi.org/10.1016/B978-0-85709-843-6.00016-0

[7] Colomera, A. and Kuilderd, H. (2015) Biotechnological Washing of Denim Jeans. In: Paul, R., Ed., Denim, Woodhead Publishing Limited, Cambridge, 357-403. https://doi.org/10.1016/B978-0-85709-843-6.00012-3

[8] Dalbaşı, E.S., Özçelik, K.G. and İlleez, A.A. (2019) A Research on the Effect of Various Laser Fading Parameters on Physical and Surface Properties of Denim Fabric. Optics and Laser Technology, 118, 28-36. https://doi.org/10.1016/j.optlastec.2019.04.030

[9] Körlü, A.E., Yapar, S., Perinçek, S., Yılmaz, H. and Bağıran, C. (2015) Dye Removal from Textile Waste Water through the Adsorption by Pumice Used in Stone Washing. Autex Research Journal, 15, 158-163. https://doi.org/10.1515/aut-2015-0012

[10] Garcia, B. (2015) Reduced Water Washing of Denim Garments. In: Paul, R., Ed., Denim, Woodhead Publishing Limited, Cambridge, 405-423. https://doi.org/10.1016/B978-0-85709-843-6.00013-5

[11] Rahman, M., Asif, A.K.M.A.H., Sarker, P. and Sarker, B. (2019) Improvement of Tensile Strength of Viscose Woven Fabric by Applying Chemical Finishes. Manufacturing Science and Technology, 6, 23-30. 
https://doi.org/10.13189/mst.2019.060201

[12] Sarker, S., Rakesh, M., Alam, M. and Roy, A. (2016) Effects of Dry Washing Process on Denim Garment. Chemical Science International Journal, 17, 1-10. https://doi.org/10.9734/CSJI/2016/29399

[13] Faruq, H., Hasan, M.Z. and Asif, A.K.M.A.H. (2020) Effect of Different Softeners on Dimensional Stability and Color Fastness Properties of Stretch Denim Fabric. Advances in Applied Sciences, 5, 112-119.

[14] Shi, W.Q., Zuo, D.Y., Chen, Y.B. and Yi, C.H. (2015) Study on Chlorine Bleaching-Washing of Denim Fabric under Ultrasonic Conditions. Key Engineering Materials, 671, 202-209. https://doi.org/10.4028/www.scientific.net/KEM.671.202

[15] Iracheta-Cárdenas, M.M., Rocha-Peña, M.A., Galán-Wong, L.J., Arévalo-Niño, K. and Tovar-Herrera, O.E. (2016) A Pycnoporus Sanguineus Laccase for Denim Bleaching and Its Comparison with an Enzymatic Commercial Formulation. Journal of Environmental Management, 177, 93-100. https://doi.org/10.1016/j.jenvman.2016.04.008

[16] Maryan, A.S. and Montazer, M. (2015) One Pot Denim Washing and Finishing Using Organo-Montmorillonite: Introducing Nano Mineral Washing and Finishing. Textile Research Journal, 85, 91-100. https://doi.org/10.1177/0040517514542143

[17] Shaheen, I.M., Mamun, M.A.A., Siddique, M.A.B. and Asif, A.K.M.A.H. (2016) Effect of Finishing Machine Parameters on Dimensional Stability of Single Lacoste Cotton Knitted Fabric. Advances in Materials, 5, 35-43.

https://doi.org/10.11648/j.am.20160505.12

[18] Asif, A.K.M.A. and Hasan, M.Z. (2018) Application of Nanotechnology in Modern Textiles: A Review. International Journal of Current Engineering and Technology, 8, 227-231. https://doi.org/10.14741/ijcet/v.8.2.5

[19] Asif, A.K.M.A.H. (2017) An Overview of Sustainability on Apparel Manufacturing Industry in Bangladesh. Science Journal of Energy Engineering, 5, 1-12. https://doi.org/10.11648/j.sjee.20170501.11

[20] Tarhan, M. and Sarışı, M. (2009) A Comparison among Performance Characteristics of Various Denim Fading Processes. Textile Research Journal, 79, 301-309. https://doi.org/10.1177/0040517508090889

[21] Siddique, M.A.B., Asif, A.K.M.A.H., Rashedul, H.K., Anwar, M.T., Saiful, I. and Nusrat, N. (2016) Study on the Effect of Dyeing and Finishing Parameters on Cotton Knitted Two Thread Fleece Fabric and 1x1 Rib Fabric. Science Research, 4, 7-10. https://doi.org/10.11648/j.sr.20160401.12

[22] Ghaani Farashahi, B., Easter, E. and Annett-Hitchcock, K. (2018) Price and Perceived Product Quality: A Comparison of Denim Jeans in Three Price Categories. Journal of Fashion Marketing and Management. An International Journal, 22, 369-386. https://doi.org/10.1108/JFMM-10-2017-0104

[23] Kalaoglu, F. and Paul, R. (2015) Finishing of Jeans and Quality Control. In: Paul, R., Ed., Denim, Woodhead Publishing Limited, Cambridge, 425-459. https://doi.org/10.1016/B978-0-85709-843-6.00014-7

[24] Abdelfattah, H.N., Sahnoun, M. and Cheikhrouhou, M. (2014) The Effect of Washing Treatments on The Sensory Properties of Denim Fabric. Textile Research Journal, 85, 150-159. https://doi.org/10.1177/0040517514542971

[25] Eryuruk, S. (2019) The Effects of Elastane and Finishing Properties on Wicking, Drying and Water Vapour Permeability Properties of Denim Fabrics. International Journal of Clothing Science and Technology, 32, 208-217. https://doi.org/10.1108/IJCST-01-2019-0003 
[26] Kan, C.W. and Yuen, C.W.M. (2012) Effect of Atmospheric Pressure Plasma Treatment on the Desizing and Subsequent Colour Fading Process of Cotton Denim Fabric. Coloration Technology, 128, 356-363. https://doi.org/10.1111/j.1478-4408.2012.00388.x

[27] Eryuruk, S. (2018) The Effects of Elastane and Finishing Processes on the Performance Properties of Denim Fabrics. International Journal of Clothing Science and Technology, 31, 243-258. https://doi.org/10.1108/IJCST-01-2018-0009

[28] Yao, J.M. and Wei, S.N. (2012) Room Temperature Cellulase Used for Washing of Denim Garments. Advanced Materials Research, 518-523, 88-92. https://doi.org/10.4028/www.scientific.net/AMR.518-523.88

[29] Talebi, S. and Montazer, M. (2020) Denim Fabric with Flame Retardant, Hydrophilic and Self-Cleaning Properties Conferring by In-Situ Synthesis of Silica Nanoparticles. Cellulose, 27, 6643-6661. https://doi.org/10.1007/s10570-020-03195-6

[30] Telli, A. and Babaarslan, O. (2016) The Effect of Recycled Fibers on the Washing Performance of Denim Fabrics. The Journal of the Textile Institute, 108, 812-820. https://doi.org/10.1080/00405000.2016.1192236

[31] Rahman, M., Asif, A.K.M.A.H., Siddiquee, M.A.B. and Rokonuzzaman, M. (2014) Effect of Shade Percentage on Various Properties of Cotton Knitted Fabric Dyed with Reactive Dyes. International Journal of Research in Engineering and Technology, 3, 339-343. https://doi.org/10.15623/ijret.2014.0302061

[32] Arikan, T., Cavusoglu, B., Alver, Y., Cil, Z.E., Akkaya, S. and Kayaoglu, B.K. (2015) Effects of Different Industrial Washing Processes on Strength and Physical Properties of Denim Fabrics. Tekstil Ve Mühendis, 22, 54-68. https://doi.org/10.7216/1300759920152210007

[33] Çelik, H.İ. and Kaynak, H.K. (2017) An Investigation on the Effect of Elastane Draw Ratio on Air Permeability of Denim Bi-Stretch Denim Fabrics. IOP Conference Series: Materials Science and Engineering, 254, Article ID: 082007. https://doi.org/10.1088/1757-899X/254/8/082007

[34] Venkatraman, P.D. and Liauw, C.M. (2019) Use of a Carbon Dioxide Laser for Environmentally Beneficial Generation of Distressed/Faded Effects on Indigo Dyed Denim Fabric: Evaluation of Colour Change, Fibre Morphology, Degradation and Textile Properties. Optics and Laser Technology, 111, 701-713. https://doi.org/10.1016/j.optlastec.2018.09.004

[35] Değırmenc1, Z. (2017) Study on the Loss of Strength of Denim-Like Knitted Fabrics after Different Washing Treatments. Fibres and Textiles in Eastern Europe, 25, 98-105. https://doi.org/10.5604/01.3001.0010.1697

[36] Ibrahim, N.A., Eid, B.M., Abdel Aziz, M.S., Hamdy, S.M. and Abd Allah, S.E. (2018) Green Surface Modification and Nano-Multifunctionalization of Denim Fabric. Cellulose, 25, 6207-6220. https://doi.org/10.1007/s10570-018-1985-y

[37] Sarker, P., Asif, A.K.M.A.H, Rahman, M., Islam, M.M. and Rahman, K.H. (2020) Green Dyeing of Silk Fabric with Turmeric Powder Using Tamarind Seed Coat as Mordant. Journal of Materials Science and Chemical Engineering, 8, 65-80. https://doi.org/10.4236/msce.2020.82007

[38] Vasile, S., De Raeve, A., Malengier, B. and Cools, J. (2019) Effect of Biaxial Stretch and Domestic Washing on Air Permeability of Elastic Knitted Fabrics for Sportswear. Fibers and Polymers, 20, 868-875. https://doi.org/10.1007/s12221-019-8871-6

[39] Juciene, M., Urbelis, V.V., Juchneviciene, Ž., Saceviciene, V. and Dobilaite, V. (2018) The Influence of Laser Treatment and Industrial Washing on Denim Fabric Tension Properties. International Journal of Clothing Science and Technology, 30, 
588-596. https://doi.org/10.1108/IJCST-03-2017-0032

[40] Chung, H. and Kim, J.Y. (2016) Effects of Washing Parameters on Dimensional Stability of Viscose Rayon Fabrics. Fibers and Polymers, 17, 1945-1954.

https://doi.org/10.1007/s12221-016-6415-x

[41] ISO 105-C10 (2006) Textiles-Tests for Color Fastness-Part C04: Color Fastness to Washing: Test 4.

[42] ISO 105-X12 (2016) Textiles-Tests for Color Fastness-Part X12: Color Fastness to Rubbing.

[43] ISO 105-B02 (2014) Textiles-Tests for Color Fastness-Part B02: Color Fastness to Artificial Light: Xenon Arc Fading Lamp Test.

[44] ISO 105-E01 (2010) Textiles-Tests for Color Fastness-Part E01: Color Fastness to Water.

[45] ISO 105-E04 (2013) Textiles-Tests for Color Fastness-Part E04: Color Fastness to Perspiration.

[46] ISO 23231 (2008) Textiles-Determination of Dimensional Change of Fabrics, Accelerated Machine Method.

[47] ISO 13934-2 (2014) Textiles-Tensile Properties of Fabrics-Part 2: Determination of Maximum Force Using the Grab Method.

[48] ISO 13937-1 (2000) Textiles-Tear Properties of Fabrics-Part 1: Determination of Tear Force Using Ballistic Pendulum Method (Elmendorf). 